\title{
Using structure- and Ligand-based pharmacophores as filters to discriminate Human Aryl Sulfotransferase 1A1 (SUL1A1) binders into substrates and inhibitors
}

\author{
Salwa M Soliman*, Gerhard Wolber \\ From 9th German Conference on Chemoinformatics \\ Fulda, Germany. 10-12 November 2013
}

Predicting metabolictransformation is one of major challenges in drug discovery [1]. Sulfotransferase 1A1 (SULT1A1), one of phase II metabolismenzymes, is the major SULT in adult liver catalysis [2]. It metabolizes many endogenous compounds and is relevant in carcinogenesis due to its ability to modify diverse promutagen and procarcinogen xenobiotics [3].

In order to make a discriminative model that classifies group of SULT1A1 binders into substrates and inhibitors, a combination of structure, ligand-based, and docking based pharmacophores have been generated and validated by Ligandscout [4].

On one hand, structure-based pharmacophores have been derived from PDB files of good binders (substrates and inhibitors). On the other hand, ligand-based interaction maps have been conducted from some drug classes that show different substrate/inhibitor activity towards SULT1A1.Finally, highly active substrates and inhibitors have been docked into the enzyme using GOLD [5], and subsequently molecular interaction fields have been developed for the most plausible poses.

As a retrospective validation, all pharmacophores simultaneously have been used to screen more than 100 SULT1A1 binders covering several activity classes and different chemical scaffolds. The model showed good discriminative power to differentiate between inhibitors, substrates and mixed substrates/inhibitors.

Published: 11 March 2014

\footnotetext{
* Correspondence: salwamosad@zedat.fu-berlin.de

Freie Universitaet Berlin, Institute of Pharmacy, Department pharmaceutical, chemistry, Koenigin-Luisestrasse 2+4, 14195 Berlin, Germany
}

\section{References}

1. Moroy G, Martiny VY, Vayer P, Villoutreix BO, Miteva MA: Toward in silico structure-based ADMET prediction in drug discovery. Drug Discov Today 2012, 17:44-55

2. Jancova P, Anzenbacher P, Anzenbacherova E: Phase II drug metabolizing enzymes. Biomed Pap Med Fac Univ Palacky Olomouc Czech Repub 2010, 154:103-116.

3. Glatt H, Pauly K, Piee-Staffa A, Seidel A, Hornhardt S, Czich A: Activation of promutagens by endogenous and heterologous sulfotransferases expressed in continuous cell cultures. Toxicol Lett 1994, 72:13-21.

4. Wolber G, Langer T: LigandScout: 3-D pharmacophores derived from protein-bound ligands and their use as virtual screening filters. J Chem Inf Model 2005, 45:160-169.

5. Verdonk ML, Cole JC, Hartshorn MJ, Murray CW, Taylor RD: Improved protein-ligand docking using GOLD. Proteins 2003, 52:609-623.

doi:10.1186/1758-2946-6-S1-P32

Cite this article as: Soliman and Wolber: Using structure- and Ligandbased pharmacophores as filters to discriminate Human Aryl Sulfotransferase 1A1 (SUL1A1) binders into substrates and inhibitors. Journal of Cheminformatics 2014 6(Suppl 1):P32.

\section{Publish with ChemistryCentral and every scientist can read your work free of charge \\ "Open access provides opportunities to our colleagues in other parts of the globe, by allowing anyone to view the content free of charge." \\ W. Jeffery Hurst, The Hershey Company. \\ - available free of charge to the entire scientific community \\ - peer reviewed and published immediately upon acceptance \\ - cited in PubMed and archived on PubMed Central \\ - yours - you keep the copyright \\ Submit your manuscript here: \\ http://www.chemistrycentral.com/manuscript/}

